\title{
Penegakan Hukum Pidana Yang Optimal (Perspektif Analisis Ekonomi Atas Hukum)
}

\author{
Oleh: Mahrus Ali \\ Mahasiswa Pascasarjana FH UII Yogyakarta \\ e-mail:Surham_02@yahoo.com
}

\begin{abstract}
Basically, economic analysis towards criminal law relates to two points namely, rationality and efficiency. Rationality denotes that a person, in committing a crime always takes the cost and benefit into account. While efficiency means that a crime offender tends to use certain way which is less costly in committing the crime. An optimum criminal law enforcement, therefore, may be achieved through a certain method which takes the following three aspects into account; the benefit which is gained by the criminal offender, the lost which is caused by such crime, and also, the expenditure caused by legal enforcement activities
\end{abstract}

Keywords: Analisis ekonomi atas hukum, rasionalitas, efisiensi, dan penegakan hukum pidana

\section{Pendahuluan}

Pengertian penegakan hukum pidana meliputi dua hal; yaitu, penegakan hukum pidana in abstracto dan penegakan hukum pidana in concreto. Penegakan hukum pidana in abstracto dikonsepsikan sebagai suatu upaya untuk menanggulangi kejahatan melalui pembentukan aturan-aturan hukum pidana yang melarang suatu aktivitas tertentu. Penegakan hukum dalam konteks ini masih berupa rumusan-rumusan aturan-aturan tertentu (pasal) yang merupakan panduan bagi masyarakat untuk tidak melakukan tindakan-tindakan yang dilarang oleh aturan itu. Singkatnya, penegakan hukum pidana in abstracto ini masih belum ditegakkan secara langsung oleh aparat penegak hokum. Hal ini berbeda halnya dengan penegakan hukum pidana in concreto yang merupakan tindakan konkret aparat penegak hukum untuk menegakkan aturan-aturan hukum pidana yang masih abstrak tersebut. Ketika ada ketentuan yang melarang 
perbuatan mencuri barang milik orang lain, ketentuan itu masih abstrak sifatnya, karena hanya berupa petunjuk tingkah laku bagi setiap orang agar tidak melakukan perbuatan mencuri. Kalau ternyata ada seseorang yang melakukan perbuatan mencuri dan si pencuri ditangkap, maka tugas aparat penegak hukum adalah menerapkan aturan tentang larangan mencuri kepada orang tersebut. Ini berarti aparat penegak hukum menerapakan aturan abstrak berupa larangan mencuri kepada hal-hal yang konkret, yakni menerapkan aturan larangan mencuri kepada orang itu. Aparat penegak hukum yang terlibat langsung dengan penegakan hukum pidana in concreto ini meliputi polisi, jaksa, hakim dan petugas pemasyarakatan.

Tentu saja dalam proses penegakan hukum ini diharapkan hasil yang optimal, sehingga aturan-aturan hukum pidana berfungsi secara efektif untuk mencegah seseorang melakukan perbuatan-perbuatan yang dilarang, dan kalau ternyata aturan-aturan itu dilanggar, aparat penegak hukum dapat menjalankan fungsinya secara efektif pula. Upaya untuk mewujudkan penegakan hukum pidana yang optimal ini meliputi berbagai macam cara dan pendekatan. Setiap cara dan pendekatan yang digunakan akan berimplikasi pada hasil yang akan dicapai.

Salah satu pendekatan yang dapat digunakan untuk mewujudkan penegakan hukum pidana yang optimal adalah pendekatan (analisis) ekonomi. Bagaimana konsep yang ditawarkan oleh pendekatan ekonomi untuk mewujudkan penegakan hukum pidana yang optimal, tulisan ini secara khusus mengkajinya. Dua hal yang penting dan perlu dikemukakan untuk mengetahui penegakan hukum pidana yang optimal dalam perspektif analisis ekonomi ini, yaitu prinsip-prinsip dasar (cara pandang/ kerja) analisis ekonomi atas hukum pidana; dan analisis ekonomi terhadap penegakan hukum pidana yang optimal.

\section{Prinsip Dasar Analisis Ekonomi atas Hukum Pidana}

Kemunculan analisis ekonomi atas hukum pidana ini pada tahun 1764 ketika Cesare Beccaria menerbitkan sebuah buku berjudul On Crimes and Punishments. Menurutnya, penjatuhan sanksi pidana seyogyanya dirancang (designed) sampai pada level tertentu untuk mengeliminasi keuntungan yang didapat oleh pelaku. ${ }^{1}$ Pemikiran Beccaria tentang

${ }^{1}$ Keith N. Hylton, "Punitive Damages and the Economics Theory of Penalties", Artikel pada Georgetown Law Journal, Vol. 87, Tahun 1998, hlm 425 
pemidanaan ini kemudian memberikan pengaruh tidak saja pada pemikir terkenal aliran utilitarianise, Jeremi Bentham, tapi juga para advokat dan ahli hokum pidana pada masa itu. Yang paling menakjubkan adalah, konsep pemidanaan yang ditawarkan Beccaria ini merubah cara pandang hukum pidana di Negara-negara Eropa yang lebih menekankan pada individualisasi pidana. $^{2}$

Dalam perkembangan berikutnya, konsep Beccaria ini seakan berjalan di tempat dan baru hidup kembali pada awal tahun 60-an setelah Calebresi dan Ronald Coase mempublikasikan tulisannya berjudul perbuatan melanggar hukum (torts) dan biaya social (social costs). Kedua tulisan itu merupakan usaha pertama bagaimana mengaplikasikan analisis ekonomi atas hukum. ${ }^{3}$ Analisis ekonomi atas hukum semakin berkembang setelah Garry Becker menghubungkannya ke dalam masalah kejahatan, diskriminasi rasial dan lain sebagainya. ${ }^{4}$

Dalam hubungan dengan kejahatan dan pidana, analisis ekonomi (ekonomi empiris) ini paling tidak memberikan tiga kontribusi penting, yaitu; pertama, ekonomi memberikan suatu model yang sederhana tentang bagaimana individu berperilaku di hadapan hukum, yang secara lebih khusus menganalisis bagaimana individu merespon kehadiran sanksi pidana. Kebanyakan dari kita melakukan yang terbaik terhadap apa yang kita punya, atau dalam bahasa ekonomi, kita memaksimalkan keuntungan di dalam melakukan suatu aktivitas tertentu; kedua, ekonomi relatif kaku

\footnotetext{
${ }^{2}$ Ibid.,

${ }^{3}$ Richard Posner, Economics Analysis of Law, Edisi Kelima, Aspen Law \& Business, New York, 1998, hlm 25

${ }^{4} \mathrm{Ibid}$., hlm 26. Analisis ekonomi atas hukum ini merubah pemikiran hukum terutama dalam kaitannya dengan pemahaman suatu aturan hukum, bahkan praktik hukum sekalipun. Sebagai buktinya, menjelang tahun 1990-an paling tidak terdapat satu orang ekonom yang menjadi staff pengajar di fakultas-fakultas hukum terbaik yang ada di Amerika Utaran, dan beberapa di antaranya berada di Eropa Barat. Mereka juga menempuh pendidikan tingkah doktor (Ph.D di bidang ekonomi dan doktor (Dj))di bidang hukum. Tidak sedikit jurnla-jurnal hukum yang ada mempublikasikan banyak tulisan yang menggunakan pendekatan ekonomi ini, bahkan ada beberapa jurnal yang secara khusus membahas masalah ini. Pengaruh ini berlanjut dan mendapat momentumnya ketika pada tahun 1991 dan 1992, dua ekonom terkemuka, Ronald Coese dan Gery Becker, mendapat hadiah nobel di bidang ekonomi. Karena prestasi ini, Bruce Acker mengatakan bahwa pendekatan ekonomi atas huku, merupakan perkembangan terpenting dalam pemikiran hukum pada abad ke dua puluh. Lihat Robert Cooter dan Thomas Ullen, Law and Economics, Cetk Ketiga, Eddison Wesley Longman Inc Amerika Serikat, 2000, hlm 2.
} 
dalam analisis empirisnya. Prioritas utama dalam analisis ekonomi empiris adalah untuk membedakan antara hubungan dan sebab. Hal ini dikarenakan para ekonom berasumsi bahwa manusia di dalam berperilaku adalah rasional dan memiliki tujuan-tujuan tertentu; dan ketiga, ekonomi menyediakan sebuah metrik yang jelas di dalam mengevaluasi sukses tidaknya suatu kebijakan hukum pidana. Dalam hal ini kriteria normatif yang digunakan adalah efisensi, dan efisensi sendiri memiliki implikasi pada penegakan hukum yang optimal. Dalam praktik, pandangan ini diimplementasikan dalam bentuk perbandingan antara biaya dan keuntungan dari suatu kebijakan. ${ }^{5}$

Secara umum dapat dikatakan bahwa prinsip utama yang digunakan untuk memahami analisis ekonomi atas hukum pidana adalah prinsip rasionalitas dan prinsip efisiensi. Prinsip rasionalitas mengandung suatu pengertian bahwa manusia di dalam melakukan suatu aktivitas tertentu, termasuk melakukan kejahatan, berpikir secara rasional dengan tujuan utamanya untuk memaksimalkan keuntungan yang diharapkan (maximizing the expected utility). ${ }^{6}$ Yang dimaksud dengan rasionalitas disini adalah memilih sarana-sarana yang paling baik untuk tujuan pemilih. ${ }^{7}$ Sebagai contoh, seseorang yang ingin tetap hangat ketika musim dingin tiba akan membandingkan semua sarana yang dapat digunakan untuk mewujudkan kehangatan dalam hubungannya dengan biaya yang harus dikeluarkan. Sarana yang dengannya biaya yang harus dikeluarkan paling sedikit akan dipilihnya sebagai sarana untuk mewujudkan kehangatan tersebut.

Konsep rasionalitas ini sesungguhnya berasal dari teori ekonomi mikro (microeconomics theory) yakni teori pilihan rasional (rational choice theory). Teori ini berkaitan dengan sejumlah asumsi tentang bagaimana orangorang merespon insentif. Penggunaan teori ini sangat penting dalam kaitannya dengan interaksi antara aturan hukum dan masyarakat. Hal ini dikarenakan hukum itu tidak hadir di ruang yang hampa. Kehadiran aturan hukum akan berdampak pada perilaku seseorang. ${ }^{8}$

${ }^{5}$ Thomas Miles, "Empirical Economics and Study of Punishment and Crime" artikel pada University of Chicago Legal Reivew, Vol 237, Tahun 2005, hlm 1-2

${ }^{6}$ Herbert Hovenkamp," Rationality in law and Economics", Artikel pada George Washington Law Review, Vol. 60, Tahun 1992, hlm 293.

${ }^{7}$ Richard A. Posner, "Rational Choice, Behavioral Economics and The Law", Artikel pada Stanford Law Review, Vol. 50 Tahun 1998, hlm 1551

${ }^{8}$ Russel B. Korobkin dan Thomas S. Ulen, "Law and Behavioral Science: Removing The Rationality Assumption from Law to Economics", Artikel pada California Law Review, Vol. 88 Tahun 2000, hlm 1055 
Pengertian rasionalitas (pilihan rasional) itu sendiri bukan pengertian yang tunggal, dalam arti tidak ada pengertian rasionalitas yang diterima secara luas. Russel B. Korobkin dan Thomas Ulen mengemukakan paling tidak ada empat pengertian tentang rasionalitas ini; pertama, manusia adalah pemaksimal yang rasional di dalam mencapai keuntungan/ tujuannya (a man is a rational maximizer of his ends). Rasionalitas di sini tanpa diikuti oleh sarana apa yang digunakan untuk memaksimalkan tujuannya (keuntungan) itu. Pengertian rasionalitas ini sebagaimana dicetuskan oleh Richard Posner merupakan pengertian yang paling lemah dan paling umum; kedua, pengertian rasinalitas dikonsepsikan dengan keuntungan yang diharapkan (the expected utility). Pengertian ini lebih kuat dibandingkan dengan pengertian yang pertama, karena di dalamnya telah menspesifikasi sarana yang dengannya pelaku akan mewujudkan/ memuaskan tujuan dan pilihannya. Ada lima syarat untuk adanya keuntungan yang diharapkan ini; yaitu; commensurability, transitivity, invariance, cancellation, dan dominance. ${ }^{9}$

Ketiga, kepentingan diri (self interest) yang mengandung arti bahwa pelaku akan berusaha mewujudkan keuntungan dan dengan sarana apa ia mewujudkan tujuan/keuntungan itu bergantung pada kepentingan masing-masing pelaku. Pengertian ini lebih konkret dibandingan dengan keuntungan yang diharapkan; dan terakhir adalah maksimalisasi kekayaan (the wealth maximization) yang mengandung arti bahwa pelaku akan berusaha untuk memaksimalkan kekayaan yang ada. Pengertian ini merupakan pengertian yang paling spesifik dan paling kuat. ${ }^{10}$

Jika konsep rasionalitas di atas dikaitkan dengan hukum pidana, asumsi yang dilahirkan adalah pelaku kejahatan merupakan mahkluk rasional ekonomis yang menimbang antara biaya yang harus dikeluarkan dari melakukan kejahatan dengan keuntungan yang akan didapat. Ketika keuntungan lebih besar dibandingkan dengan biaya yang dikeluarkan, maka pelaku akan melakukan kejahatan. ${ }^{11}$ Sebaliknya, jika keuntungan yang didapat lebih kecil dari biaya yang harus dikeluarkan, pelaku akan mengurungkan niatnya untuk melakukan kejahatan. Dengan kata lain, para

${ }^{9}$ Ibid., hlm 1061-1064

${ }^{10}$ Ibid., hlm 1064-1066

${ }^{11}$ Thomas J. Miles, "Empirical Economics and Study of Punishment and Crime", Artikel Pada University of Chicago Legal Forum, Vol. 237 Tahun 2005, hlm 238 
individu berperilaku secara rasional untuk memaksimalkan keuntugan yang mereka dapatkan (individuals behave rationally to maximize their utility). ${ }^{12}$ Mereka melakukan kejahatan ketika keuntungan dari melakukan perbuatan yang melanggar hukum melebihi biaya yang diharapkan dari pemidanaan. Biaya ini meliputi waktu yang diperlukan baik sebelum atau pada saat melakukan kejahatan, biaya untuk membeli alat, kemungkinan ditangkap, ditahan, biaya dipidana, mata pencaharian/pekerjaan yang akan hilang jika ditangkap, dan lain sebagainya. Sementara, keuntungan berupa keuntungan yang berbentuk fisik seperti harta, kekayaan, dan keuntungan yang berbentuk psikis seperti kesenangan, kepuasan, dan lain-lain.

Analisis biaya dan keuntungan ini sangat penting dalam kaitannya dengan usaha menanggulangai kejahatan. Masalah penanggulangan kejahatan berkaitan erat dengan alokasi anggaran yang tersedia, sementara analisis biaya dan keuntungan ini juga terkait dengan berapa banyak sumber daya yang harus dialokasikan untuk menanggulangi kejahatan itu. ${ }^{13}$

Gary Becker mengemukkan pemikirannya berkaitan dengan konsep rasionalitas dihubungankan dengan hukum pidana, pertama, kebijakan hukum pidana yang optimal (the optimal criminal justice policy). Pemikiran ini berkaitan dengan analisis biaya dan keuntungan (cost and benefit analysis), yang mengandung arti suatu usaha untuk mendapatkan alokasi optimal sumber daya dalam masyarakat di dalam memerangi kejahatan. Asumsi teori yang dibangun adalah, jika sanksi pidana yang ada cukup berat, setiap penjahat pasti akan mengindar dari kemungkinan ditangkap, dan hal ini akan mengurangi kejahatan. ${ }^{14}$

Kedua, keputusan individu dalam kaitannya dengan aktivitas kriminal (the individual's decision about criminal activity). Dalam hal ini, penjahat adalah seorang pelaku rasional yang menimbang antara biaya dan keuntungan, serta waktu dan sumber daya yang dialokasikan di antara

${ }^{12}$ Dan M. Kahan, “Sosial Influence, Sosial Meaning, and Deterrence", Artikel pada Virginia Law Review, Vol. 83, Tahun 1997, hlm 349

${ }^{13}$ Lewis A. Kornhauser, "On Justifying Cost and Benefit Analysis", Artikel pada Journal of Legal Studies, Vol. 29 Tahun 2000, hlm 1037-1038

${ }^{14}$ William L. Barnes Jr, "Revenge on Utilitarianism: Renouncing A Comprehensive Economics Theory of Crime and Punishment", artikel pada Indiana Law Journal, Vol. 74, tahun 1999, hlm 638 
aktivitas penjahat dan yang bukan penjahat, sehingga diketahui mana yang dapat mendatangkan keuntungan yang paling besar. Dengan kata lain, semua orang (tidak hanya penjahat) adalah pelaku rasional yang berdasarkan subjektivitasnya menimbang biaya dan keuntungan dari kegiatan yang dilakukan. Beberapa orang memilih kegiatan yang dilabeli penjahat, karena bagi mereka keuntungan yang diperoleh dari kegiatan tersebut melebihi biaya yang harus dikeluarkan. Untuk mencegah agar mereka dari melakukan tindak pidana, yang harus ditempuh adalah dengan meningkatkan biaya yang harus dikeluarkan, sehingga dengan demikian, keuntungan yang diperoleh lebih kecil. Caranya adalah dengan meningkatkan jumlah pidana yang akan dijatuhkan atau kesempatan untuk ditangkap dan diadili. Pada saat yang sama, biaya sosial yang harus ditanggung dari penegakan hukum harus ditekan sedemikian rupa sehingga berada pada posisi minimal. Artinya, biaya penegakan hukum jangan sampai melebihi kerugian sosial yang mau dicegah melalui sarana penegakan hukum. Singkatnya, untuk meminimalisir biaya sosial yang harus ditanggung adalah dengan cara meningkatkan sanksi pidana yang cukup berat serta meningkatkan jumlah penjahat yang ditangkap; dan ketiga, eksistensi kategori penjahat (the existence of criminal category). Masalah ini berhubungan dengan analisis terhadap hukum pidana substantive dan berusaha menjelaskan sampai sejauh mana kehadiran hukum pidana memang diperlukan. ${ }^{15}$ Untuk mengetahui katagori penjahat ini, perlu juga diketahui kategori kejahatan (category of crime).

Ada dua kategori dasar kejahatan yang digunakan sebagai analisis, yaitu kejahatan yang termasuk dalam kategori "malum prohibitum crimes" dan kejahatan yang termasuk dalam kategori "malum In se crimes". Yang dimaksud kategori pertama adalah suatu perbuatan disebut sebagai suatu kejahatan karena dilarang oleh undang-undang. Perbuatan itu bukan merupakan suatu kejahatan jika undang-undang tidak melarangnya. Termasuk dalam kategori malum prohibitum crimes ini adalah social torts dan paternalistic crimes yang meliputi prostituti, perjudian, penggunaan obat-obatan terlarang dan alkohol. Sedangkan yang dimaksud malum in se crimes adalah perbuatan yang memang merupakan suatu kejahatan dilihat dari sifatnya. Walaupun undang-undang tidak menyatakan bahwa perbuatan itu dilarang, tetap saja ia merupakan suatu kejahatan.

${ }^{15}$ Ibid., hlm 639 
Yang termasuk dalam kategori ini adalah kejahatan terhadap harta benda (property crimes), kejahatan terhadap orang (crimes against the person) seperti pembunuhan, pemerkosaan, perampokan, dan penyerangan, dan kejahatan yang belum lengkap/tidak sempurna (inchoate crimes) seperti percobaan (attempt) dan permufakatan jahat (conspiracy). ${ }^{16}$

Prinsip kedua analisis ekonomi atas hukum pidana adalah prinsip efisiensi yang mengandung makna penghematan, pengiritan, ketepatan, atau pelaksanan sesuai dengan tujuan. Efisiensi berkaitan dengan tujuan dan sarana yang digunakan untuk mencapai tujuan. Jika sarana yang ingin dicapai membutuhkan lebih banyak biaya dibandingkan dengan tujuan yang ingin dicapai, maka hal itu dikatakan tidak efisien. Sebaliknya, jika penggunaan sarana membutuhkan lebih sedikit biaya yang harus dikeluarkan dibandingkan dengan tujuan yang ingin dicapai, maka hal itu dikatakan efisien.

Dalam kaitannya dengan analisis ekonomi atas hukum pidana, efisiensi berkaitan dengan dua hal; pertama, apakah perbuatan-perbuatan yang ingin ditanggulangi dengan hukum pidana tidak banyak memerlukan biaya untuk menanggulanginya sehingga keuntungan yang hendak diraih darinya lebih besar; dan kedua, apakah sanksi pidana yang dijatuhkan lebih besar/berat dibandingkan dengan keuntungan yang diraih pelaku dari melakukan perbuatan pidana. Jika sanksi pidana lebih berat dari biaya yang harus dikeluarkan oleh pelaku, dapat dipastikan bahwa pelaku akan menghindar untuk melakukan kejahatan.

Analisis ekonomi berkaitan dengan prinsip efisiensi ini jika dihubungkan dengan penjatuhan sanksi pidana bagi pelaku kejahatan, yang pertama kali harus diperhatikan adalah bentuk-bentuk sanksi pidana apa saja yang tersedia yang akan dijatuhkan kepadanya. Kemudian, dari bentuk-bentuk sanksi pidana yang ada, dianalisis mana yang paling efisien dilihat dari prinsip biaya dan keuntungan. Umumnya, bentuk-bentuk sanksi pidana berupa pidana mati, pidana seumur hidup, pidana penjara, dan pidana denda. Dalam konteks analisis ekonomi bentuk sanksi pidana yang paling efisien dan cocok digunakan dalam kaitannya dengan prinsip biaya dan keuntungan adalah pidana mati dan pidana denda. Sedangkan pidana penjara dilihat dari analisis ekonomi atas hukum pidana kurang sesuai. Penggunaan sanksi pidana penjara dalam konteks ini pada

${ }^{16}$ Ibid., hlm 9-12 
kenyatannya memerlukan biaya sosial yang sangat tinggi (high social cost of imprisonement), dan itu semua harus ditanggung oleh negara. Biaya ini meliputi biaya langsung dari membangun suatu gedung penjara, pemeliharaannya, menggaji pegawai-pegawai yang bertugas di penjara, dan biaya kesempatan yang hilang dari produktivitas bagi mereka yang dipenjara. ${ }^{17}$ Belum lagi biaya hidup setiap orang yang dimasukkan ke penjara akibat perbuatan yang dilakukan.

Pidana denda, yang merupakan bentuk sanksi keuangan (monetary sanction), adalah pidana yang efisien karena penjatuhannya tidak memerlukan biaya apapun; ia hanya berkaitan dengan kewajiban pelaku untuk membayar sejumlah uang kepada Negara. Negara sendiri tidak mengeluarkan biaya apapun ketika menjatuhkan sanksi pidana denda. Oleh karena itu, efisiensi pidana denda tidak diragukan dalam analisis ekonomi atas hukum pidana. Namun demikian, untuk menentukan bahwa sanksi pidana denda dikatakan efisien dan dapat mencegah pelaku untuk melakukan kejahatan, bergantung pada lima faktor; pertama, asset yang dimiliki pelaku. Semakin kecil kekayaan (asset) yang ada, semakin kecil pula eksistensi pidana denda di dalam mencegah pelaku melakukan kejahatan. Dikatakan tidak mungkin pelaku dijatuhi pidana denda sementara dia sendiri tidak memiliki banyak kekayaan untuk membayar denda itu; kedua, kemungkinan pelaku untuk tidak dijatuhi sanksi pidana. Semakin besar kemungkinan ini, semakin tinggi sanksi pidana dijatuhkan untuk mencegah kejahatan. Jika kemungkinan untuk tidak dijatuhi sanksi pidana ini setengah persen $(1 / 2 \%)$, beratnya pidana denda harus dinaikkan dua kali lipat. Jika kemungkinannya sepertiga persen (1/3\%), beratnya pidana denda dinaikkan tiga kali lipat, dan seterusnya; ketiga, tingkat keuntungan yang diperoleh dari melakukan kejahatan. Semakin besar keuntungan itu, semakin tinggi sanksi pidana dibutuhkan untuk mencegah kejahatan, dan juga semakin besar kesempatan dari jumlah denda yang dijatuhkan dari kekayaan yang dimiliki pelaku; keempat, kemungkinan bahwa tindak pidana akan mengakibatkan kerugian, dan kelima, besarnya kerugian yang ditumbulkan. ${ }^{18}$

${ }^{17}$ Robert Cooter dan Thomas Ulen, op.cit., hlm 468

${ }^{18}$ Steven Shavell, "Criminal Law and the Optimal Use of Nonmonetary Sanction As Deterrence", Artikel Pada Columbia Law Review, Vol. 85 Tahun 1985, hlm 12361238 
Dilihat dari teori pemidanaan, analisis ekonomi ini menggunakan teori pencegahan (deterrence). Asumsi teori ini adalah, manusia merupakan makhluk rasional. Implikasinya, ketika seseorang melakukan kejahatan, maka sanksi pidana yang dijatuhkan harus melebihi seriusitas tindak pidana. Teori pencegahan yang dimaksud adalah pencegahan umum (general deterrence), bukan pencegahan khusus (special deterrence). Penjatuhan sanksi pidana bertujuan untuk mencegah seseorang atau orang lain/ masyarakat melakukan kejahatan. Sanksi pidana dijatuhkan agar pelaku dan orang lain tidak melakukan kejahatan itu, karena kalau itu yang terjadi, sanksi pidana akan dijatuhkan untuk kedua kalinya. ${ }^{19}$

Analisis ekonomi atas hukum pidana sebagaimana dijelaskan di atas, hanya dapat mampu mencegah kejahatan yang berkaitan dengan ekonomi. Artinya, motif pelaku melakukan kejahatan adalah untuk mendapatkan keuntungan yang bersifat ekonomis. Untuk kejahatankejahatan yang tidak bermotif ekonomi, analisis ekonomi atas hukum pidana ini tidak dapat diterapkan.

Dalam kaitannya dengan penegakan hukum pidana yang optimal, analisis ekonomi memberikan sejumlah "aturan" bagaimana penegakan hukum pidana itu dapat berjalan secara optimal. Tentu saja masalah untuk dan rugi (cost and benefit principle) masih digunakan sebagai titik pijak di dalam menganalisis apakah penegakan hukum pidana dikatakan optimal atau tidak.

\section{Penegakan Hukum Pidana yang Optimal; Sebuah Analisis Ekonomi}

Prinsip utama dalam penegakan hukum pidana yang optimal didasarkan pada pemikiran tentang maksimalisasi kesejahteraan sosial (to maximize social welfare). ${ }^{20}$ Pemerintah di dalam merancang kebijakan, termasuk kebijakan melarang perbuatan-perbuatan tertentu (in abstracto), harus memperhatikan maksimalitas keuntungan yang akan diperoleh. Dalam konteks analisis ekonomi atas hukum pidana, kesejahteraan sosial dapat ditempuh dengan memperhatikan jumlah keuntungan yang

\footnotetext{
${ }^{19}$ William J. Barnes Jr, Revenge On Utilitarianism.....op.cit, hlm 630-631

${ }^{20}$ Nuno Garoupa dan Daniel Klerman, "Optimal Law Enforcement with A RentSeeking Government", Artikel pada American Law and Economics Review, Vol. 4, Tahun 2002, hlm 116
} 
diperoleh pelaku dari melakukan perbuatan yang dilarang, dikurangi kerugian yang disebabkan oleh perbuatan itu, dan pengeluaran yang dikeluarkan dalam rangka penegakan hukum. ${ }^{21}$

Kerugian akibat tindak pidana ini meliputi kerugian sosial yang ditimbulkan, biaya yang harus dikeluarkan oleh korban potensial untuk melakukan pencegahan agar tidak menjadi korban, dan kerugian yang secara langsung dialami oleh korban. ${ }^{22}$ Sementara, biaya penegakan hukum pidana meliputi biaya pencegahan, pengungkapan, penangkapan, dan penjatuhan sanksi pidana. ${ }^{23}$ Semua itu harus diukur dan dibandingkan dengan jumlah keuntungan yang diperolah pelaku dari melakukan tindak pidana.

Jika kerugian akibat tindak pidana (setelah diuangkan) dan biaya yang harus dikeluarkan oleh pemerintah untuk menanggulangi tindak pidana itu melalui aparat penegak hukum ternyata lebih besar dibandingkan dengan jumlah keuntungan yang diperoleh pelaku dari melakukan tindak pidana, maka optimalisasi penegakan hukum tidak akan terwujud. Oleh karena itu, yang perlu dilakukan adalah dengan menggunakan instrumen yang lain di dalam mencegah tindak pidana itu terjadi. Dengan kata lain, perbuatan-perbuatan yang hendak dilarang dan ternyata biaya penegakan hukumnya ketika terjadi pelanggaran lebih besar dari keuntungan yang akan diperoleh, seyogyanya tidak perlu dilarang dan ditanggulangi dengan instrumen hukum pidana.

Hal lain yang perlu dilakukan adalah dengan mempertinggi kemungkinan pelaku tindak pidana untuk ditangkap, dipidana, dan dijatuhi pidana yang berat, karena dengan itu kesejahteraan sosial dapat terwujud. Ketika kemungkinan ditangkap tinggi, maka penegakan hukum terhadap hal itu akan optimal, karena tidak akan banyak orang yang melakukan tindak pidana, dan dengan begitu, tidak banyak biaya yang harus dikeluarkan untuk menanggulangi tindak pidana dan membiayai operasionalisasi penegakan hukumnya. Begitu juga dengan kemungkinan dipidana dengan pidana yang tinggi yang melebihi keuntungan yang

${ }^{21}$ Ibid., hlm 117

${ }^{22}$ Mark A. Cohen, "The Economics of Crime and Punishment: Implications for Sentencing of Economic Crime and New TechNology Offences", Artikel pada George Mason Law Review, Vol. 9 Tahun 2000, hlm 506-507

${ }^{23}$ Ibid., hlm 504 
diperoleh pelaku. ${ }^{24}$ Karena dengan itu, pelaku akan menanggung semua biaya dari tindakannya itu. Pemikiran ini umunya disebut dengan pemidanaan yang efisien. ${ }^{25}$

Sebagai contoh bagaimana mengaplikasikan pemidaan yang efisien sebagai berikut; jika pelaku menyebabkan sebuah kerugian sebesar Rp. 1000 dollar, dan kemungkinan untuk tidak dijatuhi sanksi pidana sebesar $50 \%$ atau kemungkinan untuk dipidana adalah $50 \%$, maka pidana yang diharapkan dijatuhkan kepadanya sebesar 500 dollar. Jumlah ini jelas tidak efisien, karena pelaku akan mendapatkan keuntungan dari tindak pidana yang dilakukan jika ia dipidana. Dihadapkan pada pidana yang 500 dollar itu, penderita potensial akan menghabiskan biaya hanya sampai 500 dollar untuk menghindari kerugian. Sementara, pelaku jelas tidak akan menghabiskan 600 dollar untuk menghindari kerugian (dijatuhi pidana). Jumlah itu tidak efisien karena masyarakat menginginkan pelaku dikenakan biaya 600 dollar. Karena kesempatan ditangkap dan dipidana $50 \%$, maka pidana yang dijatuhkan kepada pelaku harus ditingkatkan dua kali lipat, yaitu sebesar 2000 dollar. Hanya dengan itulah, pelaku tidak melakukan tindak pidana. Angka 2000 itu meliputi kerugian yang secara langsung dialami oleh korban, biaya sosial, biaya korban potensial, dan biaya penegakan hukum.

Dalam analisis ekonomi atas hukum pidana, dikenal dua model yang dapat digunakan untuk mewujudkan penegakan hukum pidana yang optimal, yaitu shaping the individual's apportunities dan shaping the individual's preferences. Yang pertama memiliki konsepsi bahwa seseorang secara rasional memilih kesempatan-kesempatan yang ada untuk mewujudkan kepuasan yang paling besar berdasarkan pilihan yang ada. Sementara yang kedua memiliki konsepsi bahwa seseorang akan bertindak secara rasioanl selama pilihan-pilihan yang dimiliki lengkap, dan dia akan

${ }^{24}$ David D. Friedman, "Should the Characteristics of Victims and Criminals Count? Payne v Tennessee and Two Views of Efficient Punishment", Artikel pada Boston College Law Review, Vol. 34 Tahun 1993, hlm 732-733. Untuk mengetahui masalah sanksi pidana ini khususnya dalam analisis ekonomi atas hukum pidana, baca Robert Cooter, "Prices and Sanctios", Artikel pada Columbia Law Review, Vol. 84, Tahun 1984, hlm 1524-1531

${ }^{25}$ Op.cit., hlm 733

${ }^{26}$ Kenneth G. Dau-Schmidr, "an Aconomic Analysis of the Criminal Law as A Preference-Shaping Policy", Artikel pada Duke Law Journal, tanpa Vol, Tahun 1990, hlm 3-4 
memilih kesempatan yang di dalamnya terdapat keuntungan yang paling besar berdasarkan pilihan-pilihan yang dimiliki. ${ }^{26}$

Seseorang akan melakukan tindak pidana berdasarkan kesempatan dan pilihan yang dimiliki. Ketika kesempatan yang dimiliki besar, agar seseorang itu tidak melakukan kejahatan, yang harus dilakukan adalah dengan memperbesar kemungkinan ditangkap, dipidana dan dijatuhi dengan sanksi pidana yang besar (berat) pula. Begitu juga ketika pilihanpilihan untuk melakukan tindak pidana lengkap, ia akan memiliki banyak kesempatan untuk melakukan kejahatan. Hanya dengan cara itulah penegakan hukum pidana akan optimal, sehingga kesejahteraan sosial yang menjadi tujuan utama dapat terwujud.

Di samping itu, upaya yang dapat dilakukan adalah dengan menyamakan kesempatan baik kesempatan untuk melakukan tindak pidana maupun kesempatan untuk tidak melakukan tindak pidana. ${ }^{27}$ Ketika kesempatan antara melakukan dan tidak melakukan tindak pidana sama, maka biaya yang diperlukan dalam penegakan hukum ketika terjadi tindak pidana akan optimal. Tidak akan banyak orang yang melakukan tindak pidana. Penegakan hukum pidana yang dapat menurunkan angka kejahatan dikatakan optimal, dan itu dikatakan mencegah kejahatan. ${ }^{28}$

Penegakan hukum pidana yang optimal dalam analisis ekonomi atas hukum pidana ini harus dalam batas-batas yang masih ditorelansi, sehingga tidak menimbulkan apa yang disebut dengan penegakan hukum yang berlebihan (overonforcement). Penegakan hukum yang berlebihan terjadi manakala jumlah keseluruhan sanksi pidana yang dijatuhkan kepada pelanggar melebihi jumlah optimal dari upaya pencegahan. Penegakan hukum yang berlebihan dapat pula terjadi ketika kerugian yang ingin dijatuhkan kepada pelaku melebihi upaya pencegahan yang diharapkan dari dijatuhinya sanksi kepadanya. ${ }^{29}$

Ketika seseorang merugikan orang lain sebesar 1000 dollar, akan dikatakan berlebihan jika ia dijatuhi sanksi pidana denda sebesar 3000 dollar, jika pengenaan denda sebesar 2000 dollar dikatakan dapat mencegahnya dari melakukan tindak pidana. Ekses yang akan timbul jika

${ }^{27}$ Ibid., hlm 5

${ }^{28}$ Ibid

${ }^{29}$ Richard A. Bierschbach, "Overenforcement", Artikel pada Georgetown Law Journal, Vol. 93, Tahun 2005, hlm 1743-1744 
penegakan hukum pidana tidak memperhatikan aspek pencegahan yang diharapkan mampu mencegah seseorang melakukan tindak pidana adalah potensi pelanggaran hak asasi manusia yang dilakukan oleh aparat penegak hukum terhadap pelaku. Dapat saja pelaku tindak pidana dipidana melebihi batas maksimal dari kesalahan yang dilakukan.

\section{Penutup}

Analisis ekonomi atas hukum pidana berkenaan dengan suatu konsepsi bahwa manusia adalah makhluk rasional yang di dalam berperilaku/melakukan tindak pidana menimbang antara biaya yang dikeluarkan dengan keuntungan yang diperoleh. Jika keuntungan yang akan diperoleh ternyata, berdasarkan kalkulasinya, melebihi biaya yang dikeluarkan, maka seseorang akan melakukan tindak pidana. Analisis ekonomi atas hukum pidana juga mendasari konsepsinya pada prinsip efisiensi, suatu prinsip yang berkaitan dengan pencapaian tujuan dengan sarana-sarana yang paling sedikit di dalam menghabiskan sumber daya.

Dikaitkan dengan sanksi pidana, prinsip efisiensi ini mensyaratkan bahwa sanksi pidana yang dijatuhkan kepada pelaku tindak pidana harus melebihi (lebih berat) keuntungan yang diperoleh pelaku. Yang diperlukan dalam hal ini adalah mempertinggi kemungkinan pelaku untuk ditangkap, ditahan, dipidana dan dijatuhi pidana yang berat. Semakin tinggi kemungkinannya, semakin kecil pelaku melakukan kejahatan, begitu juga sebaliknya.

Mengenai penegakan hukum pidana yang optimal, konsep utama analisis ekonomi adalah maksimalisasi kesejahteraan sosial. Kesejahteraan sosial dapat ditempuh dengan memperhatikan jumlah keuntungan yang diperoleh pelaku dari melakukan perbuatan yang dilarang, dikurangi kerugian yang disebabkan oleh perbuatan itu, dan pengeluaran yang dikeluarkan dalam rangka penegakan hukum. Kalau ternyata kerugian akibat perbuatan pelaku dan biaya yang harus dikeluarkan dalam penegakan hukum lebih kecil dibandingkan dengan keuntungan yang diperoleh pelaku, maka penegakan hukum pidana dikatakan optimal. Begitu juga sebaliknya. 


\section{Daftar Pustaka}

Dan M. Kahan, “Sosial Influence, Sosial Meaning, and Deterrence”, Artikel pada Virginia Law Review, Vol. 83, Tahun 1997

David D. Friedman, "Should the Characteristics of Victims and Criminals Count? Payne v Tennessee and Two Views of Efficient Punishment", Artikel pada Boston College Law Review, Vol. 34 Tahun 1993

Herbert Hovenkamp,"Rationality in law and Economics", Artikel pada George Washington Law Review, Vol. 60, Tahun 1992

Keith N. Hylton, "Punitive Damages and the Economics Theory of Penalties", Artikel pada Georgetown Law Journal, Vol. 87, Tahun 1998

Kenneth G. Dau-Schmidr, "an Aconomic Analysis of the Criminal Law as A Preference-Shaping Policy", Artikel pada Duke Law Journal, tanpa Vol, Tahun 1990

Lewis A. Kornhauser, “On Justifying Cost and Benefit Analysis”, Artikel pada Journal of Legal Studies, Vol. 29 Tahun 2000

Mark A. Cohen, "The Economics of Crime and Punishment: Implications for Sentencing of Economic Crime and New TechNology Offences", Artikel pada George Mason Law Review, Vol. 9 Tahun 2000

Nuno Garoupa dan Daniel Klerman, “Optimal Law Enforcement with A Rent-Seeking Government", Artikel pada American Law and Economics Review, Vol. 4, Tahun 2002

Richard A. Bierschbach, "Overenforcement", Artikel pada Georgetown Law Journal, Vol. 93, Tahun 2005

Richard A. Posner, "Rational Choice, Behavioral Economics and The Law", Artikel pada Stanford Law Review, Vol. 50 Tahun 1998

, Economics Analysis of Law, Edisi Kelima, Aspen Law \& Business, New York, 1998

Robert Cooter dan Thomas Ullen, Law and Economics, Cetk Ketiga, Eddison Wesley Longman Inc Amerika Serikat, 2000

, "Prices and Sanctios", Artikel pada Columbia Law Review, Vol. 84, Tahun 1984

Russel B. Korobkin dan Thomas S. Ulen, "Law and Behavioral Science: Removing The Rationality Assumption from Law to Economics", Artikel pada California Law Review, Vol. 88 Tahun 2000

Steven Shavell, "Criminal Law and the Optimal Use of Nonmonetary Sanction As Deterrence", Artikel Pada Columbia Law Review, Vol. 85 Tahun 1985 
Thomas J. Miles, "Empirical Economics and Study of Punishment and Crime", Artikel Pada University of Chicago Legal Forum, Vol. 237 Tahun 2005

William L. Barnes Jr, “Revenge on Utilitarianism: Renouncing A Comprehensive Economics Theory of Crime and Punishment", artikel pada Indiana Law Journal, Vol. 74, tahun 1999 